\title{
Explosive demographic expansion by dreissenid bivalves as a possible result of astronomical forcing
}

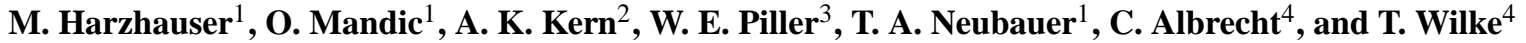 \\ ${ }^{1}$ Natural History Museum Vienna, Geological-Paleontological Department, Vienna, Austria \\ ${ }^{2}$ State Museum of Natural History in Stuttgart, Rosenstein, Stuttgart, Germany \\ ${ }^{3}$ University of Graz, Institute of Earth Sciences, Graz, Austria \\ ${ }^{4}$ Justus Liebig University Giessen, Institute of Animal Ecology \& Systematics, Giessen, Germany
}

Correspondence to: M. Harzhauser (mathias.harzhauser@nhm-wien.ac.at)

Received: 25 June 2013 - Published in Biogeosciences Discuss.: 19 July 2013

Revised: 13 November 2013 - Accepted: 20 November 2013 - Published: 23 December 2013

\begin{abstract}
Human induced range expansions of invasive dreissenid bivalves are of great concern. However, the underlying biological processes are only poorly understood, partly due to the lack of information on natural expansion events. Here we use the extinct bivalve species Sinucongeria primiformis as a model organism for testing natural (i.e. preAnthropocene) blooms of dreissenid species in a lacustrine system of Lake Pannon during the Tortonian ( 10.5 Myr; late Miocene). A total of 600 samples from a consecutive core were evaluated for the relative abundance of this pavement-forming mollusc, which cover about eight millennia of late Miocene time with a decadal resolution.

Our data indicate that the settlement by bivalves in the offshore environment was limited mainly by bottom water oxygenation, which follows predictable and repetitive patterns through time. These population fluctuations might be related to solar cycles: successful dreissenid settlement is recurring in a frequency known as the lower and upper Gleissberg cycles with 50-80 and 90-120 yr periods. These cycles appear to control regional wind patterns, which are directly linked to water mixing of the lake. This is modulated by the even more prominent $500 \mathrm{yr}$ cycle, which seems to be the most important pacemaker for Lake Pannon hydrology.
\end{abstract}

\section{Introduction}

The range expansion of dreissenid bivalves is a potential threat to native fluvial and lacustrine ecosystems in Europe and North America. Massive settlement within few years as well as negative influence on power plant cooling systems and fish densities makes them also a socio-economic concern (Bij de Vaate et al., 2010). Problematic extant dreissenids are the zebra mussel, Dreissena polymorpha (Pallas, 1771), and the eastern European quagga mussel, Dreissena (Pontodreissena) rostriformis bugensis (Andrusov, 1897). Dreissena polymorpha, originated during the Pliocene in the Black Sea area (Babak, 1983), but spread within the last $200 \mathrm{yr}$ throughout Europe due to artificial transcontinental waterways (Karatayev et al., 2007). Similarly, Dreissena (Pontodreissena) rostriformis bugensis started to spread from its native range in the Don and Bug rivers (Orlova et al., 2004) and has already arrived in western and central Europe and North America, where it starts to outcompete Dreissena polymorpha in some areas (Zhulidov et al., 2010; McMahon, 2011; Heiler et al., 2013; Bij de Vaate et al., 2013; Matthews et al., 2014). Recently, Wilke et al. (2010) documented that even the two endemic carino mussels (Dreissena (Carinodreissena) presbensis; Kobelt, 1915, and D. C. blanci Westerlund, 1890) - originally endemic to the Balkan lakes Ohrid/Prespa and Trichonis - started to invade artificial water bodies. Size and density of recent dreissenid populations follow different trajectories (Churchill, 2013). Many populations display stable cycles of population size on sub-decadal scales (Burla and Ribi, 1998; Strayer and Malcolm, 2006; Strayer et al., 2011). Others are characterised by boom-and-bust patterns (Stanczykowska, 1977; Casagrandi et al., 2007) and some studies revealed irregular population behavior (Nalepa et al., 2006). The trigger mechanisms are complex and result from an interplay of recruitment, survivorship of post-recruits and 
changing environmental conditions (Strayer and Malcolm, 2006; Churchill, 2013).

All these range expansions and population size variations are happening within the Anthropocene (sensu Crutzen and Stoermer, 2000). The success of dreissenids is usually attributed to human influence. Furthermore, the anthropogenic global warming is considered to positively affect the invasiveness of dreissenids (Schindler, 2001), although the connection remains vague.

In this study we used the bivalve species Sinucongeria primiformis (Papp, 1951) as a model organism for testing natural (i.e. pre-Anthropocene) blooms of dreissenid species. Specifically, we studied whether dreissenids have explosively taken over aquatic ecosystems in the past and analyse their connection with climate. The "natural laboratory" for this investigation is the ancient, long-lived Lake Pannon, which provides an excellent fossil record.

\section{Material and methods}

\subsection{Geological setting}

The investigated bivalve assemblages lived in Lake Pannon, which covered the Pannonian Basin complex in central and south-eastern Europe during late Miocene and Pliocene times (11.6 to $\sim 5.5 \mathrm{Myr})$. This lake formed a several hundred metres deep, long-lived, brackish and slightly alkaline lacustrine system (Magyar et al., 1999; Harzhauser et al., 2004; Piller et al., 2007; Harzhauser and Mandic, 2008). Lake Pannon is a textbook example for endemic evolution with spectacular radiations in many groups such as the melanopsid gastropods and dreissenid bivalves (e.g. Geary, 1990; Müller et al., 1999; Geary et al., 2002; Harzhauser and Mandic, 2008; Neubauer et al., 2013).

The studied samples derive from a drilled core in the opencast pit Hennersdorf south of Vienna $\left(48^{\circ} 05^{\prime} 52.6^{\prime \prime} \mathrm{N}\right.$, $\left.16^{\circ} 21^{\prime} 15.8^{\prime \prime} \mathrm{E}\right)$, where offshore clays of Lake Pannon are exposed (Fig. 1). The mollusc fauna represents assemblages of the regional Pannonian stage, corresponding to the middle Tortonian (Magyar et al., 1999). Magnetostratigraphy allowed a correlation with the normal chron C5n (Magyar et al., 1999). Correlation with astronomically tuned well logs in the Vienna Basin suggests an absolute age of 10.5-10.4 Myr for the core (Harzhauser et al., 2004; Lirer et al., 2009). These clay deposits are famous for their frequently occurring dreissenid coquinas, which can be followed over large areas in the entire Vienna Basin pointing to major settlement events (Fig. 1b). The conspicuous succession of dreissenid coquinas was already recognised in the field by Harzhauser and Mandic (2004), who tentatively assigned the cyclicity to Milankovitch forcing. Later, based on deep drillings in the Vienna Basin, Lirer et al. (2009) and Paulissen et al. (2011) showed that the sedimentation rates in the Vienna Basin during the late Miocene were much higher than calculated by
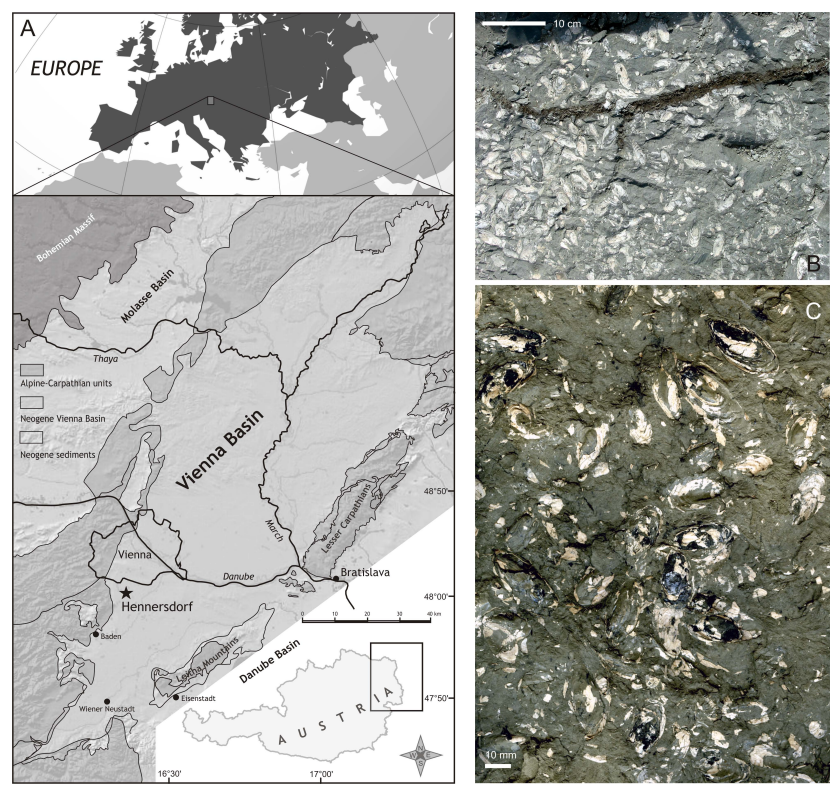

Fig. 1. (A) Geological map of the Vienna Basin showing the position of the investigated core at Hennersdorf. (B) A dreissenid pavement in the Hennersdorf pit during field work (with a fossil twig). This pavement can be followed over more than $400 \mathrm{~m}$ distance from the outcrop area. (C) Moderately dense coquina of Sinucongeria primiformis. The shells are articulated and the sediment fill of the valves is coated with pyrite indicating rather abrupt installation of dysoxic conditions killing off the population.

Harzhauser and Mandic (2004), excluding the presence of several precession cycles in the about $20 \mathrm{~m}$ thick succession of the clay pit. Based on cross-correlations with these astronomically tuned well data, Kern et al. (2012a) reinterpreted the section and proposed a sedimentation rate of ca. $10 \mathrm{~mm}$ per 13-14 yr. This study was performed on the same core that provided the herein studied mollusc samples. Kern et al. (2012a, 2013) analysed a broad range of geophysical, geochemical and biological proxies, all of which exhibit a set of comparable cyclicities with similar frequencies.

The ratios of the frequency peaks correspond to the ratios between known solar cycles, allowing a tuning of the sedimentary record and a best-fit estimate of the sedimentation rate. The proposed age model for the core results in a resolution of roughly $13 \mathrm{yr}$ per centimetre and a total of $8000 \mathrm{yr}$ for the whole $6 \mathrm{~m}$ core. Palynological data of Kern et al. (2012a) point to an at least warm-temperate climate with a mean annual temperature between 15.6 and $20.8^{\circ} \mathrm{C}$, with a cold season range of $5.0-13.3^{\circ} \mathrm{C}$ and a warm season range from 24.7 to $27.9^{\circ} \mathrm{C}$. The mean annual precipitation (MAP) was varying from $\sim 820 \mathrm{~mm}$ up to $\sim 1530 \mathrm{~mm}$, displaying a clear seasonality with a wet phase of 204-236 mm and a dry phase of 9-24 mm per month.

The offshore environment captured by the core did not change much as the shore of Lake Pannon was established in about a $3-5 \mathrm{~km}$ distance at that time (Harzhauser et al., 
2008; Kern et al., 2012a). Based on the relative position of the palaeo-shoreline and unpublished seismic data, a water depth of a few tens of metres is most likely. Deposition was below the fair-weather wave base, which is estimated for Lake Pannon to have ranged around $10-15 \mathrm{~m}$ by KorpásHódi (1983). Significant lake level changes during the investigated time interval can be excluded based on the dinoflagellates record, which is typical for "offshore" settings of Lake Pannon with constantly high amounts of Impagidinium (ca. 20-40\%) (Kern et al., 2013). As documented in other studies on Lake Pannon, such water table changes would be very clearly reflected by shifts in the dinoflagellate assemblages (Harzhauser et al., 2008; Kern et al. 2012b).

\subsection{Drilling and core handling}

In November 2009 a $15 \mathrm{~m}$-long core with a diameter of $15 \mathrm{~cm}$ was drilled at the Wienerberger AG clay pit in Hennersdorf. The lowermost $6 \mathrm{~m}$ were taken without a core break. This is the most uniform part with respect to lithology (dark grey clay, low to absent bioturbation). Further analyses concentrated on this deepest segment (see Kern et al., 2012a, 2013, for details and sampling protocol). After cutting the core into two halves, one halve was sliced, following a strict $1 \mathrm{~cm}$-sampling protocol. The samples were dried, weighed and treated with $\mathrm{H}_{2} \mathrm{O}_{2}$ before sieving with 125,250 and $500 \mu \mathrm{m}$-mesh-size sieves. As the bivalve shells were fragmented during washing, no individuals could be counted. Therefore, the abundance of bivalves was evaluated by using semi-quantitative categories: $0=$ no fragments, $1=$ rare fragments, $2=$ frequent shell fragments, and $3=$ dense coquina layers with numerous fragments. Statistical analyses were performed first on these semiquantitative raw data, on a detrended data set and on a 3 point-running-mean data set (trend removed) - all with very similar results. Detrending of the data was performed with the program PAST (Hammer et al., 2001) to remove any linear trend from a data set by means of subtraction of a linear regression line from the values. This procedure was necessary to dampen the overall trend towards higher abundance of shells throughout the record, which would have masked the higher frequency cycles. To detect and describe cyclicities, the software PAST (Hammer et al., 2001) was used for Lomb-Scargle periodograms and REDFIT analysis (Schulz and Mudelsee, 2002) and the software AnalySeries (Paillard et al., 1996) for filtering. REDFIT is a program to remove unwanted red noise from the data set, which is a common problem for unevenly spaced time series (due to sampling or changes in sedimentation rate). The Monte Carlo method was applied to test a bias-corrected spectrum and only peaks above the $99 \%$ confidence interval in the REDFIT spectrum were considered. Additionally, a wavelet analysis was performed to detect potential nonstationary periodicities.

\section{Palaeontological analyses}

\subsection{Preservation, autecology and life style}

The mollusc fauna of the offshore areas of Lake Pannon, as represented at the clay pit Hennersdorf, consists nearly exclusively of dreissenid and cardiid bivalves; gastropods are largely confined to nearshore environments. The inventory and spatial distribution of the taxa is described in detail in Harzhauser and Mandic (2004) and Harzhauser et al. (2008). Accordingly, the succession comprises several very distinct bivalve assemblages, which usually are nearly monospecific. Within the studied interval, the coquina layers are formed mainly by the small-sized, thin-shelled dreissenid bivalve Sinucongeria primiformis (Papp, 1951). This was observed in the field, where this core interval was exposed during exploration by the Wienerberger AG company, as well as during sample preparation in the laboratory. Therefore, despite the fragmentary preservation after sample processing, the taxonomic assignment is reliable.

\subsection{Species studied}

The genus Sinucongeria (Lörenthey, 1894) belongs to the dreissenid subfamily Dreissenomyinae (Babak, 1983). Sinucongeria primiformis is the stratigraphically oldest record of this group and was considered a late Miocene offshoot of primitive Mytilopsis-like Dreisseninae (Papp, 1951; Marinescu, 1977). Indeed, its habitus as well as an integripalliate to slightly sinupalliate mantle scar coincides with modioliform Dreisseninae (Harzhauser and Mandic, 2010), suggesting an epifaunal mode of life. During the middle Pannonian (ca. 10.5 Myr) it is ubiquitous in Lake Pannon, forming dense pavements by monospecific gregarious assemblages at many sections (Fig. 1b) over huge areas. These have been considered "boom-and-bust" populations by Harzhauser and Mandic (2004) as most specimens are articulated and fully grown. Sinucongeria primiformis might represent an "explosive opportunist" sensu Levinton (1970) comparable to modern invasive Dreissena species. Shell cavities are commonly incrusted with pyrite (Fig. 1c), pointing to anoxia as a cause for their sudden death. Concluding, the pavements are interpreted to represent autochthonous in situ census assemblages or "snapshots" sensu Kidwell (1998). No indication for transport or winnowing can be documented from the data.

\section{Results}

In total, 600 samples have been evaluated to document fluctuations in bivalve occurrence within the $6 \mathrm{~m}$-long record (Fig. 2; Supplement 1). Distribution and abundance are characterised by an alternation of dense pavements and samples devoid of molluscs. There is a trend towards increasing dreissenid abundance with time from sample 1500 onwards (linear correlation $r=0.573, p<0.001$ ). The lower 
part of the core reveals only infrequent intervals of settlement (samples 1540-1510, 1480-1460, and 1380-1350) and few short settlement phases separated by long intervals of absence of any molluscs. From sample 1280 onwards, a phase of nearly continuous settlement starts, separated by short intervals of population breakdowns. The longer phases of settlement are also not uniform but exhibit a characteristic pattern. This starts with the presence of single shells, passing into moderately dense shell accumulations and culminating in extremely dense coquinas, followed by a gradual or sometimes abrupt decline. As several prominent cyclicities have already been detected for various biotic and abiotic proxies in the core by Kern et al. (2012a, 2013), it might be expected that comparable periodicities influence the bivalve signal.

Indeed, the spectral analyses of the raw data and of a 3 point-running-mean data set reveal several statistically significant peaks, passing the $99 \%$ confidence interval. The Lomb-Scargle periodogram shows a very prominent peak at $32.8-35.5 \mathrm{~cm}$, a set of three peaks from 56.4 to $72.6 \mathrm{~cm}$ and a strong peak centred at $145 \mathrm{~cm}$ (Fig. 3a). A weaker peak appears at $100 \mathrm{~cm}$ only in the 3 point-running-mean data. The REDFIT analysis reveals three additional higher frequency peaks at 5.5-5.5, 7.5 and $10.8 \mathrm{~cm}$ (Fig. 3b). Increasing the number of segments in the REDFIT analysis reduces noise and then also confirms the dominant peak at $35-36 \mathrm{~cm}$ of the Lomb-Scargle periodogram, whilst high frequency cycles become less prominent (Fig. 4 right).

The wavelet analysis (Fig. 4) confirms the presence of the low-frequency signals especially in the upper half of the core, whereas the high-frequency cycles revealed by REDFIT form discrete bundles (e.g. between sample 1280-1200, 1120-1060).

The frequency-ratio between the significant peaks in the Lomb-Scargle periodogram calls for attention as the low frequency peaks might be only multiples of the prominent peak at $35.5 \mathrm{~cm}$. Therefore, Gaussian filters were applied, centred at $10-11,33-36,57-73$ and $145-150 \mathrm{~cm}$ (Fig. 5). The filtered data document that the higher frequency filter at 10-11 and $33-36 \mathrm{~cm}$ explain most of the observed fluctuations of the record. The visual comparison of both curves suggests that the fit is good especially in the upper half of the core, whilst in the lower part the filter coincides with the "signalbundles" observed in the wavelets. The low-frequency filter at $145-150 \mathrm{~cm}$, in contrast, resolves especially the large-scale pattern below sample 1050 but has a poor fit with the uppermost record. The filter spanning the triplet of peaks in the power spectra from 57 to $73 \mathrm{~cm}$ has the lowest fit with the record below sample 1050 and only a moderately good fit above. Thus, tentatively we interpret this frequency band as harmonic of the higher frequency signals.

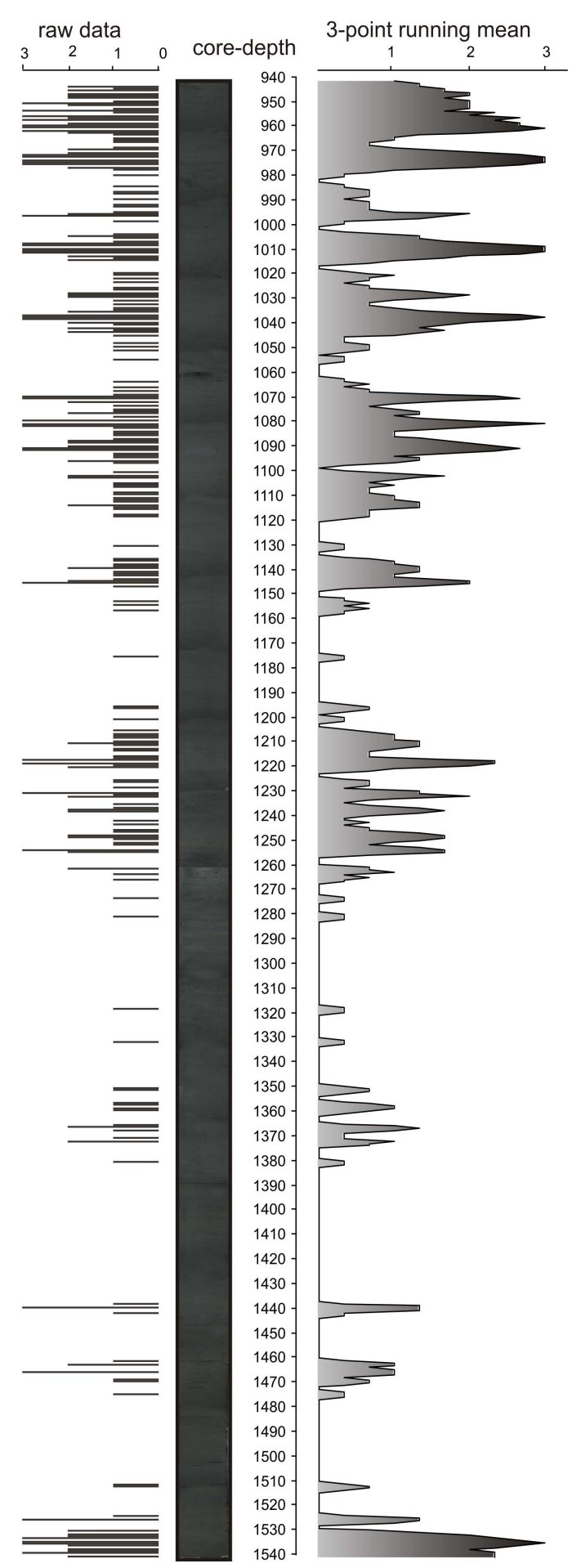

Fig. 2. Illustration of the core and relative dreissenid abundance indicated on a semi-quantitative scale $(0=$ no shells; $1=$ rare debris or single shells; $2=$ loose coquina; $3=$ dense shell bed), left: raw data, right: 3 point-running mean; core depth in $\mathrm{cm}$ (corresponds to sample numbers $1540-940$; i.e. 600 samples). 

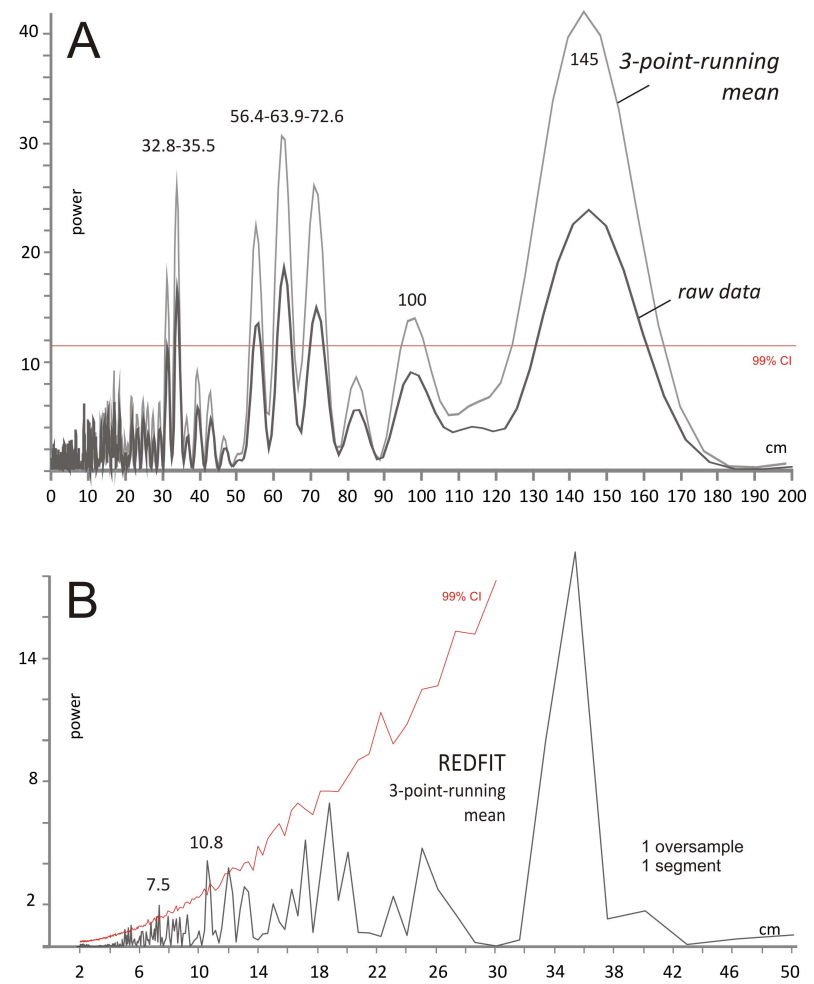

Fig. 3. Lomb-Scargle (a) and REDFIT (b) periodograms with indication of the $99 \%$ confidence interval. Longer frequencies are better revealed in the power spectra, whilst short cyclicities are better supported by the REDFIT-analysis.

\section{Discussion}

The overall pattern describes a distinct amelioration of ecological conditions for dreissenid settlement from bottom to top. A similar trend is observed in the number of cooccurring ostracods, which are most abundant in the upper part of the core, whilst the lower half is characterised by long-lasting and severe population collapses, punctuated by short phases of ostracod settlement (Kern et al., 2012a). This large-scale trend is explained by the fact that Lake Pannon changed from a transgressive phase into a high-stand phase with increasing bottom water oxygenation and a progradation of the coast. A few metres above the core top, this shift is documented in the clay pit by coquinas of coastaldeltaic origin, transported offshore by storms, by an increase of silt content, and by sediment oxygenation, reflected in a colour change from grey-blue towards yellow (Harzhauser and Mandic, 2004; Kern et al., 2012a). The influx of organic matter, however, was not the driving force for dreissenid settlement. TOC (total organic carbon)-data are available for the lower $150 \mathrm{~cm}$ of the core (samples 1540-1390) and were published in Kern et al. (2013). The values are rather low ranging between 0.56 and $1.19 \%$, and the fluctuations are minor. These values are distinctly below those of typical stress environments over-enriched in organic loading with values above 3.5-3.9\% (e.g. Hyland et al., 2005; Magni et al., 2008). Moreover, there is no correlation of higher values with low coquina densities or population collapse. Similarly, layers with very dense coquinas do not coincide with exceptionally low TOC values. Therefore, the suspended organic particles were not deposited in such a high amount that gills of bivalves could be blocked.

Bioturbation is nearly absent aside from minor traces in the lowermost part of the core. Therefore, the fine-scale fluctuations of bottom water oxygenation are clearly unrelated to bioturbation. This suggests that only the habitability of the lake bottom was changing over time.

Kern et al. (2012a, 2013) documented comparable frequency peaks in several biotic and abiotic proxies in the same core with two discrete intervals of 4-6 and 8-9 cm, representing 54.8-82.2 and 109.6-123.3 yr. These values range well within the expected ranges of the lower Gleissberg cycle with a 50-80 yr period (Ogurtsov et al., 2002; de Jager et al., 2010) and the upper Gleissberg cycle with a $90-120$ yr period (Ogurtsov et al., 2002). As these solar cycles are quasiperiodic, their repetition varies in time and distance, which results in a set of peaks rather than a single peak. Interestingly, this periodicity is reflected more intensively in the pollen record, the gamma radiation and the carbonate content record. Kern et al. (2013) concluded that these repetitive changes were more likely related to wind strengths and/or wind direction rather than to variations in precipitation. Such differences in wind regime might be important for lake water mixing and as a consequence result in a better oxygenation of bottom waters, supporting settlement by dreissenids.

As shown by the wavelet analysis, the high-frequency cycles are best expressed during maxima of the $\sim 35 \mathrm{~cm}$ cycle, pointing to a clear modulation. This very prominent peak appears with a comparable bandwidth also in the magnetic susceptibility signal (MS), where it is the most dominant cycle (Kern et al., 2012a). Kern et al. (2012a) interpreted this pattern to reflect phases of increased sulfur bacteria activity due to low bottom water oxygenation, modifying the original MS signal. The coincidence of favourable bottom oxygenation and dreissenid settlement is especially striking when the filtered MS record of Kern et al. (2012a) is compared with the filtered dreissenid record. Both behave anticyclic with highest dreissenid densities during phases with lowest MS values (Fig. 5c, e).

The same cycle is also influencing the settlement by ostracods, suggesting it a major pacemaker of lake bottom ecology. Based on the age model of Kern et al. (2012a), this important cycle represents the unnamed $500 \mathrm{yr}$ solar cycle, which is also well documented from Holocene $\mathrm{C}^{14}$ data (Solanki et al., 2004; Kern et al., 2012a). The overall increasingly more effective bottom water oxygenation as reflected by the general trend of increased settlement is thus clearly modulated by this cycle, which in turn modulates the expression of the high frequency Gleissberg cycles. 


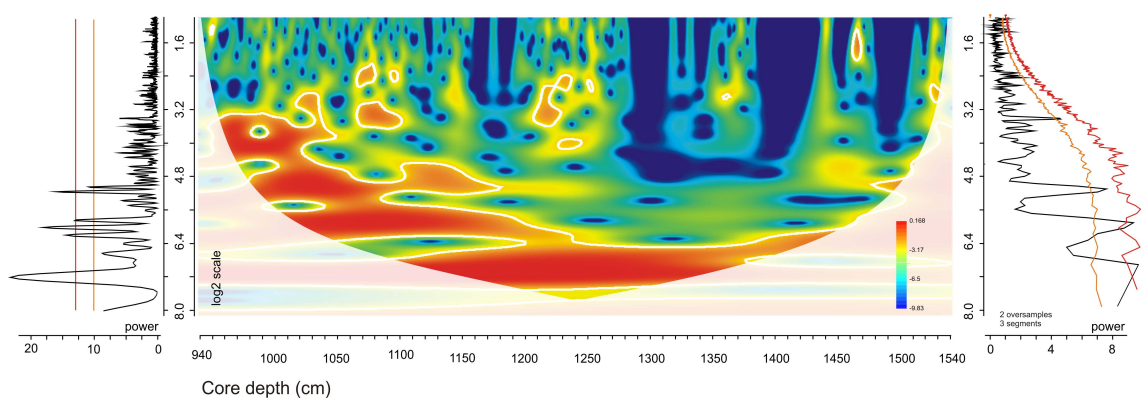

Fig. 4. Morlet wavelet power spectrum based on the 3 point-running mean data set (white line indicates significance level, $p=0.05$ ). The Lomb-Scargle (left) and the REDFIT (right) periodograms illustrated previously in Fig. 3 are now drawn along a log2-scale (vertical axis) for easier comparison of frequency peaks in the power spectra in Fig. 3 with those in the wavelet spectrum (orange and red lines represent 95 and $99 \%$ confidence intervals). The colour scale represents the strength (i.e. power) of the signal in the wavelet spectrum - red for the high, blue for the low power. Horizontal scale of the wavelet analysis plot represents the core depth in centimetres.

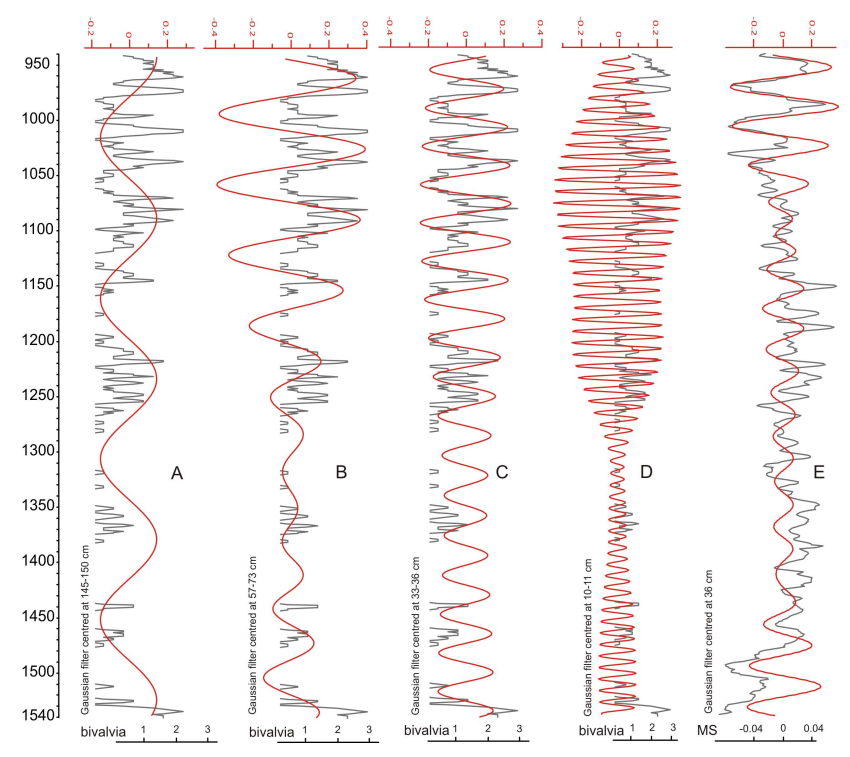

Fig. 5. Gaussian filters have been applied to the bivalve data according to the dominant periods revealed by the periodograms in Figs. 3 and 4. These filters are centered at 10-11, 33-36, 57-73 and 145$150 \mathrm{~cm}$ (A-D). The two high-frequency filters explain most of the observed data. $\mathbf{E}$ shows magnetic susceptibility data from Kern et al. (2012a). The Gaussian filter centered at $36 \mathrm{~cm}$ represents the hypothetical $500 \mathrm{yr}$ cycle and is anticyclic compared with the bivalve record (C).

Harzhauser and Mandic (2004, Fig. 4) showed that coeval (but not necessarily identical) mass-occurrence layers of dreissenids are documented from the entire shelf of Lake Pannon (e.g. Marinescu, 1985; Skerlj, 1985; Stevanovic, $1985 \mathrm{a}, \mathrm{b}, \mathrm{c})$. These occurrences document that explosive demographic expansions by dreissenid bivalves were a widespread phenomenon.

\section{Conclusions}

This is the first study documenting the waxing and waning of dreissenid bivalve populations over a continuous time interval of approximately eight millennia of late Miocene time with a decadal resolution. Sinucongeria primiformis was among the most successful species settling in offshore environments of Lake Pannon, where it formed vast pavements. The tolerance for poorly oxygenated lake bottoms close to the epilimnion/hypolimnion boundary was probably the key adaptation to outcompete other species in this lacustrine offshore environment.

The position of the investigated core documents an overall positive shift of the ecological window suitable for dreissenid settlement, which is related to a long-term lake highstand. This trend is strongly modulated by high-frequency cycles, which are probably related to solar cycles. The highest frequency cycles become gradually more significant when lower frequency cycles are well established as seen in the upper half of the core.

Thus, solar forcing might have played an important role for lake hydrology, which in turn allowed population blooms during phases of improved ecological conditions. The repeated establishment of dysoxic conditions was lethal for the populations and is reflected by pyrite incrustations in the shell cavities. The cyclicities might be expressions of the Gleissberg cycles and the $500 \mathrm{yr}$ cycle, indicating that bottom water oxygenation was strongly influenced by these solar cycles.

This example shows that dreissenid bivalves may be pioneers, which quickly dominate aquatic ecosystems even in pre-Anthropocene records. The surprisingly strong influence of solar forcing on the success of the Miocene dreissenids is an overlooked aspect for predicting the population dynamics of extant dreissenids. To understand the success of extant Dreissena species in a larger context, analyses of Holocene lake records would be urgently needed. Such data could also help to identify and further quantify natural population 
fluctuations ("background noise"), often compounding human impact analyses. These analyses typically consider only short time periods and may thus not accurately differentiate between natural and anthropogenic factors.

Moreover, historical demographic data could also help to better understand the complex interplay of biotic and global abiotic factors triggering large-scale population expansions. This, in turn, may enable the improvement of existing invasion models, particularly in respect to niche opportunities and invasion dynamics.

\section{Supplementary material related to this article is available online at http://www.biogeosciences.net/10/ 8423/2013/bg-10-8423-2013-supplement.pdf.}

Acknowledgements. This study was supported by the Austrian Science Fund FWF grant P21414-B16 and contributes to the FWF project P25365-B25. We thank G. Van der Velde (Biodiversity Center, Leiden), Wolfgang Kiessling (GeoZentrum Nordbayern) and an anonymous reviewer for the constructive comments on an earlier draft of the paper. Many thanks to D. Danielopol (University of Graz) for the stimulating discussions on Lake Pannon ecology.

Edited by: W. Kiessling

\section{References}

Andrusov, N. I.: Fossile und lebende Dreissenidae Eurasiens, Erstes Supplement, Trav. Soc. Nat. St. Petersbourg, 29, 59-132, 1897.

Babak, E. V.: Pliotseno I Chevertichnye Dreissenid (Dreissenidae, Bivalvia) Evksinskogo Basseina (The Pliocene and Quarternary Dreissenidae of the Euxinian Basin), Tr. Paleontol. Inst., Akad. Nauka SSSR, 204, 1-104, 1983.

Bij de Vaate, A., Rajagopal, S., and van der Velde, G.: The zebra mussel in Europe: summary and synthesis, in: The Zebra Mussel in Europe, edited by: van der Velde, G., Rajagopal, S., and Bij de Vaate, A., Backhuys Publishers, Leiden, 415-421, 2010.

Bij de Vaate, A., van der Velde, G., Leuven, R. S. E. W., and Heiler, K. C. M.: Spread of the Quagga Mussel (Dreissena rostriformis bugensis) in Western Europe. Chapter 6. in: Quagga and Zebra mussles: Biology, impacts and control, edited by: Nalepa, T. and Schlosser, D. W., 2nd edition, CRS Press, Boca Raton, 83-92, 2013.

Burla, H. and Ribi, G.: Density variation of the zebra mussel Dreissena polymorpha in Lake Zürich, from 1976 to 1988, Aquat. Sci., 60, 145-156, 1998.

Casagrandi, R., Mari, L., and Gatto, M.: Modeling the local dynamics of the zebra mussel (Dreissena polymorpha), Freshwater Biol., 52, 1223-1238, 2007.

Churchill, J. C.: Spatio-temporal spawning and larval dynamics of a zebra mussel (Dreissena polymorpha) population in a North Texas Reservoir: implications for invasions in the southern United States, Aquatic Invasions, 8, online first, 2013.

Crutzen, P. J. and Stoermer, E. F.: The "Anthropocene", Global Change Newsletter, 41, 17-18, 2000. de Jager, C., Duhau, S., and van Geel, B.: Quantifying and specifying the solar influence on terrestrial surface temperature, J. Atmos. Sol-Terr. Phy., 72, 926-937, 2010.

Geary, D. H.: Patterns of evolutionary tempo and mode in the radiation of Melanopsis (Gastropoda: Melanopsidae), Paleobiology, 16, 492-511, 1990.

Geary, D. H., Staley, A. W., Müller, P., and Magyar, I.: Iterative changes in Lake Pannon Melanopsis reflect a recurrent theme in gastropod morphological evolution, Paleobiology, 28, 208-221, 2002.

Hammer, Ø., Harper, D. A. T., and Ryan, P. D.: PAST: Palaeontological Statistics Software package for education and data analysis, Palaeontol. Electron., 4, 1-9, 2001.

Harzhauser, M. and Mandic, O.: The muddy bottom of Lake Pannon-a challenge for dreissenid settlement (Lake Miocene; Bivalva), Palaeogeogr. Palaeocl., 204, 331-352, 2004.

Harzhauser, M. and Mandic, O.: Neogene lake systems in Central and South-Eastern Europe: faunal diversity, gradients and interrelations, Palaeogeogr. Palaeocl., 260, 417-434, 2008.

Harzhauser, M. and Mandic, O.: Neogene dreissenids in Central Europe: evolutionary shifts and diversity changes, in: The Zebra Mussel in Europe, edited by: van der Velde, G., Rajagopal, S., and Bij de Vaate, A., Backhuys Publishers, Leiden, 11, 426-478, 2010.

Harzhauser, M., Daxner-Höck, G., and Piller, W. E.: An integrated stratigraphy of the Pannonian (Late Miocene) in the Vienna Basin, Austrian J. Earth Sci., 95/96, 6-19, 2004.

Harzhauser, M., Kern, A., Soliman, A., Minati, K., Piller, W. E., Danielopol, D. L., and Zuschin, M.: Centennial- to decadal scale environmental shifts in and around Lake Pannon (Vienna Basin) related to a major Lake Miocene lake level rise, Palaeogeogr. Palaeocl., 270, 102-115, 2008.

Heiler, K. C. M., Bij de Vaate, A., Ekschmitt, K., Oheimb, P. V. von, Albrecht, C., and Wilke, T.: Reconstruction of the early invasion history of the quagga mussel (Dreissena rostriformis bugensis) in Western Europe, Aquatic Invasions, 8, 53-57, 2013.

Hyland, J., Balthis, L. W., Karakassis, I., Magni, P., Petrov, A., Shine, J. R., Vestergaard, O., and Warwick, R.: Organic carbon content of sediments as an indicator of stress in the marine benthos, Mar. Ecol-Prog Ser., 295, 91-103, 2005.

Karatayev, A. Y., Padilla, D. K., Minchin, D., Boltovskoy, D., and Burlakova, L. E.: Changes in global economies and trade: the potential spread of exotic freshwater bivalves, Biol. Invasions, 9 , 161-180, 2007.

Kern, A. K., Harzhauser, M., Piller, W. E., Mandic, O., and Soliman, A.: Strong evidence for the influence of solar cycles on a Late Miocene Lake system revealed by biotic and abiotic proxies, Palaeogeogr. Palaeocl., 329, 124-136, 2012a.

Kern, A. K., Harzhauser, M., Soliman, A., Piller, W. E., and Gross, M.: Precipitation driven decadal scale decline and recovery of wetlands of Lake Pannon during the Tortonian, Palaeogeogr. Palaeocl., 317, 1-12, 2012b.

Kern, A. K., Harzhauser, M., Soliman, A., Piller, W. E., and Mandic, O.: High-resolution analysis of Upper Miocene lake deposits: evidence for the influence of Gleissberg-band solar forcing, Palaeogeogr. Palaeocl., 370, 176-183, 2013.

Kidwell, S. M.: Time-averaging in the marine fossil record: overview of strategies and uncertainties, Geobios, 30, 977-995, 1998. 
Kobelt, W.: Iconographie der Land- \& Süsswasser-Mollusken mit vorzüglicher Berücksichtigung der europäischen noch nicht abgebildeten Arten von E. A. Rossmässler, Neue Folge, Zwanzigster Band, 1-81, Kreidel, Wiesbaden, 1915.

Korpás-Hódi, M.: Palaeoecology and Biostratigraphy of the Pannonian Mollusca fauna in the Northern Foreland of the Transdanubian Central Range, A Magyar Áll. Föld. Int. Èvkönyve, 96, 1-141, 1983.

Levinton, J. S.: The paleoecological significance of opportunistic species, Lethaia, 3, 69-78, 1970.

Lirer, F., Harzhauser, M., Pelosi, N., Piller, W. E., Schmid, H. P., and Sprovieri, M.: Astronomically forced teleconnection between Paratethyan and Mediterranean sediments during the Middle and Late Miocene, Palaeogeogr. Palaeocl., 275, 1-13, 2009.

Lörenthey, E.: Die pontische Fauna von Kurd im Comitate Tolna, Földtani Közlöny, A Magyar Földtani Tarsulat Folyoirata, 24, 148-161, 1894.

Magni, P., Rajagopal, S., van der Velde, G., Fenzi, G., Kassenberg, J., Vizzini, S., Mazzola, A., and Giordani, G.: Sediment features, macrozoobenthic asemblages and trophic relationships $\left(\delta^{13} \mathrm{C}\right.$ and $\delta{ }^{15} \mathrm{~N}$ analysis) following a dystrophic event with anoxia and sulphide development in the Santa Giusta lagoon (western Sardinia, Italy), Mar. Pollut. Bull., 57, 125-136, 2008.

Magyar, I., Geary, D. H., and Müller, P.: Integrated Paleogeographic evolution of the Late Miocene Lake Pannnon in Central Europe, Palaeogeogr. Palaeocl., 147, 151-167, 1999.

Marinescu, F. L.: Genre Dreissenomya Fuchs (Bivalvia, Heterodonta), Inst. Géol. Géophy. Mém., 26, 75-118, 1977.

Marinescu, F. L.: Der östliche Teil des Pannonischen Beckens (Rumänischer Sektor): Das Pannonien s. str. (Malvensien), in: M6 Pannonien (Slavonien und Serbien), edited by: Papp, A., Jámbor, A., and Steininger, F., Akadémiai Kiadó, Budapest, 144149, 1985.

Matthews, J., Van der Velde, G., Bij de Vaate, A., Collas, F. P. L., Koopman, K. R., and Leuven R. S. E. W.: Rapid range expansion of the invasive quagga mussel in relation to zebra mussel presence in The Netherlands and Western Europe, Biol. Invasions, online first, doi:10.1007/s10530-013-0498-8, 2014.

McMahon, R. F.: Quagga mussel (Dreissena rostriformis bugensis) population structure during the early invasion of Lakes Mead and Mohave January-March 2007, Aquatic Invasions, 6, 131-140, 2011.

Müller, P., Geary, D. H., and Magyar, I.: The endemic molluscs of the Late Miocene Lake Pannon: their origin, evolution, and family-level taxonomy, Lethaia, 32, 47-60, 1999.

Nalepa, T. F, Fanslow, D. L., and Pothoven, S. A.: Recent changes in density, biomass, recruitment size structure, and nutritional state of Dreissena populations in southern Lake Michigan, J. Great Lakes Res., 36, 5-19, 2010.

Neubauer, T. A., Harzhauser, M., and Kroh, A.: Phenotypic evolution in a fossil gastropod species lineage: evidence for adaptive radiation?, Palaeogeogr. Palaeocl., 370, 117-126, 2013.

Ogurtsov, M. G., Nagovitsyn, Y. A., Kocharov, G. E., and Jungner, H.: Long-period cycles of the sun's activity recorded in direct solar data and proxies, Sol. Phys., 211, 371-394, 2002.
Orlova, M. I., Muirhead, J. R., Antonov, P. I., Scherbina, G. H., Starobogatov, Y. I., Biochino, G. I., Therriault, T. W., and MacIsaac, H. J.: Range expansion of quagga mussels Dreissena rostriformis bugensis in the Volga River and Caspian Sea basin, Aquat. Ecol., 38, 561-573, 2004.

Paillard, D., Labeyrie, L., and Yiou, P.: Macintosh program performs timeseries analysis, Trans. Am. Geophy. Union, 77, 379, 1996.

Pallas, P. S.: Reise durch verschiedene Provincen des Russischen Reichs. Vol. 1. Kayserlichen Academie der Wissenschaften, St. Petersburg, 1-504, 1771.

Papp, A.: Das Pannon des Wiener Beckens, Mitt. Geol. Ges. Wien, 39-41, 99-193, 1951.

Paulissen, E., Luthi, S. M., Grunert, P. Ćorić, S., and Harzhauser, M.: Integrated high-resolution stratigraphy of a Middle to Late Miocene sedimentary sequence in the central part of the Vienna Basin, Geol. Carpath., 62, 155-169, 2011.

Piller, W. E., Harzhauser, M., and Mandic, O.: Miocene Central Paratethys stratigraphy - current status and further directions, Stratigraphy, 4, 71-88, 2007.

Schindler, D. W.: The cumulative effects of climate warming and other human stresses on Canadian freshwaters in the new millennium, Can. J. Fish. Aquat. Sci., 58, 18-29, 2001.

Schulz, M. and Mudelsee, M.: REDFIT: estimating red-noise spectra directly from unevenly spaced paleoclimatic time serie, Comput. Geosci., 28, 421-426, 2002.

Skerlj, Z.: Ablagerungen des Pannonien in Slowenien (Jugoslawien), in: M6 Pannonien (Slavonien und Serbien), edited by: Papp, A., Jámbor, A., and Steininger, F., Akadémiai Kiadó, Budapest, 85-89, 1985.

Solanki, S. K., Usoskin, I. G., Kromber, B., Schüssler, M., and Beer, J.: Unusual activity of the Sun during recent decades compared to the previous 11000 years, Nature, 431, 1084-1087, 2004.

Stanczykowska, A.: Ecology of Dreissena polymorpha (Pall.) (Bivalvia) in lakes, Polskie Archiw. Hydrobiol., 24, 461-530, 1977.

Stevanovic, P.: Das Pannonian im Kolubara-Becken, West-Serbien, in: M6 Pannonien (Slavonien und Serbien), edited by: Papp, A., Jámbor, A., and Steininger, F., Akadémiai Kiadó, Budapest, 9598, 1985a.

Stevanovic, P.: Das Kohlebecken von Kreka bei Tuzla, Bosnien (Jugoslawien), in: M6 Pannonien (Slavonien und Serbien), edited by: Papp, A., Jámbor, A., and Steininger, F., Akadémiai Kiadó, Budapest, 242-250, 1985b.

Stevanovic, P.: Karagaca (Jugoslawien) Stratotypus des Serbien Stevanovic 1975, in: M6 Pannonien (Slavonien und Serbien), edited by: Papp, A., Jámbor, A., and Steininger, F., Akadémiai Kiadó, Budapest, 256-258, 1985c.

Strayer, D. L. and Malcolm, H. M.: Long-term demography of a zebra mussel (Dreissena polymorpha) population, Freshwater Biol., 51, 117-130, 2006.

Strayer, D. L., Cid, N., and Malcom, H. M.: Long-term changes in a population of an invasive bivalve and its effects, Oecologia, 165, 1063-1072, 2011. 
Westerlund, C. A.: Katalog der in der paläarctischen Region lebenden Binnenconchylien, 1-224, Johansson, Karlshamn, 1890.

Wilke, T., Schultheiß, R., Albrecht, C., Bornmann, N., Trajanovski, S., and Kevrekidis, T.: Native Dreissena freshwater mussels in the Balkans: in and out of ancient lakes, Biogeosciences, 7, 3051-3065, doi:10.5194/bg-7-3051-2010, 2010.
Zhulidov, A. V., Kozhara, A. V., Scherbina, G. H., Nalepa, T. F., Protasov, A., Afanasiev, S. A., Pryanichnikova, E. G., Zhulidov, D. A., Gurtovaya, T. Yu., and Pavlov D. F.: Invasion history, distribution, and relative abundances of Dreissena bugensis in the old world: a synthesis of data, Biol. Invasions, 7, 1923-1940, 2010. 